INTERJURISDICTIONAL HOUSING PRICES AND SPATIAL AMENITIES:
WHICH MEASURES OF HOUSING PRICES REFLECT LOCAL PUBLIC GOODS?

\author{
H. Spencer Banzhaf \\ Omar Farooque \\ Working Paper 17809 \\ http://www.nber.org/papers/w17809
NATIONAL BUREAU OF ECONOMIC RESEARCH
1050 Massachusetts Avenue
Cambridge, MA 02138
February 2012

This paper was begun under the Andrew Young Summer Policy Internship program, under NSF award 0452702. We thank Kelly Bishop, James Marton, and especially Nicolai Kuminoff for comments. The views expressed herein are those of the author and do not necessarily reflect the views of the National Bureau of Economic Research.

NBER working papers are circulated for discussion and comment purposes. They have not been peerreviewed or been subject to the review by the NBER Board of Directors that accompanies official NBER publications.

(C) 2012 by H. Spencer Banzhaf and Omar Farooque. All rights reserved. Short sections of text, not to exceed two paragraphs, may be quoted without explicit permission provided that full credit, including (C) notice, is given to the source. 
Interjurisdictional Housing Prices and Spatial Amenities: Which Measures of Housing Prices

Reflect Local Public Goods?

H. Spencer Banzhaf and Omar Farooque

NBER Working Paper No. 17809

February 2012

JEL No. H4,R2,R30

\section{ABSTRACT}

Understanding the spatial variation in housing prices plays a crucial role in topics ranging from the cost of living to quality-of-life indices to studies of public goods and household mobility. Yet analysts have not reached a consensus on the best source of such data, variously using self-reported values from the census, transactions values, tax assessments, and rental values. Additionally, while most studies use micro-level data, some have used summary statistics such as the median housing value.

Assessing neighborhood price indices in Los Angeles, we find that indices based on transactions prices are highly correlated with indices based on self-reported values, but the former are better correlated with public goods. Moreover, rental values have a higher correlation with public goods and income levels than either asset-value measure. Finally, indices based on median values are poorly correlated with the other indices, public goods, and income.

H. Spencer Banzhaf

Department of Economics

Andrew Young School of Policy Studies

Georgia State University

P.O. Box 3992

Atlanta, GA 30302

and NBER

hsbanzhaf@gsu.edu

Omar Farooque

Department of Economics

302 Arthur Andersen Hall

2001 Sheridan Road, Evanston, IL 60208-2600

omarfarooque2015@u.northwestern.edu 


\title{
Interjurisdictional Housing Prices and Spatial Amenities: Which Measures of Housing Prices Reflect local Public Goods?
}

\author{
H. Spencer Banzhaf \\ (Georgia State University, NBER, PERC) \\ Omar Farooque \\ (Northwestern University)
}

Housing is the most important asset and largest expenditure category in most households' budgets. Accordingly, accurate data on the value of homes is a lynchpin in many economic studies. For example, because housing accounts for about 30 percent of households' expenditures, housing costs play a key role in computing geographic comparisons in the cost-of-living, such as the US ACCRA index, as well as intertemporal indices of inflation.

An accurate representation of home values is also a critical step in many empirical studies of local public goods. Through the process of capitalization, home values are deeply intertwined with spatial public goods such as school quality, crime, air quality, hazardous waste sites, and green spaces, and the taxes that pay for them. The differences in housing values associated with differences in these public goods and taxes have long been used by economists to infer people's demand for such goods. ${ }^{1}$ Prominent examples of such "hedonic" methods include applications to intercity quality-of-life measures (Albouy 2010, Blomquist, Berger and Hoehn 1988), education (Black 1999, Figlio and Lucas 2004), crime (Bishop and Murphy 2011), racial segregation (Bajari and Kahn 2005), air quality (Chay and Greenstone 2005, Grainger 2011, Smith and Huang 1995), superfund sites (Gamper-Rabindran, Mastromonaco, and Timmins 2011, Greenstone and Gallagher 2008), cancer risks (Davis 2004), and property taxes (Palmon and Smith 1998).

More recently, economists have emphasized the importance of general equilibrium effects in evaluating households' demand for public goods and the effects of public policies $(\mathrm{Ku}-$ minoff, Smith, and Timmins 2010). Changing the geographic distribution of local public goods will induce households to move, with attending effects on local real estate prices, local peer

\footnotetext{
${ }^{1}$ Early examples include Oates (1969) and Ridker and Henning (1967). For an overview of the literature, see Palmquist (2004).
} 
groups, and tax revenues. For example, Sieg et al. (2004) show that improving air quality in some neighborhoods can cause what they call "environmental gentrification," which benefits landlords at the expense of poor renters, leading to very different distributional welfare effects in general equilibrium (see also Tra 2010). Calabrese et al. (2006) consider the implications of household sorting on endogenous neighborhood demographics for voting on public goods. Bayer, Ferreira, and McMillan (2007) emphasize the importance of accounting for endogenously formed neighborhood demographics and their interactions with school quality and unobserved locational goods. Walsh (2007) illustrates the importance of endogenous development patterns when understanding the effect of open space policies. And Kuminoff (2011) emphasizes the importance of the choice of job location as well as residential location when households maximize utility over public goods, commutes, and housing prices.

To incorporate these housing feedbacks in an equilibrium model, an emerging strategy in the public economics literature is to use a two-stage discrete-continuous model, in which households first choose a community and then a quantity of continuous housing. A crucial step in this strategy is the estimation of community-level price indices. From there, one approach then leverages insights from hierarchical models, in which the demand for high-quality communities makes them more expensive, to estimate community-level quality indices based on these price indices. These quality indices, in turn, can then be decomposed into a function of observed public goods (see e.g. Calabrese et al. 2006, Epple and Sieg 1999, Kuminoff 2011, and Sieg et al. 2004 ). A second approach applies insights from the industrial organization literature (Berry, Levinson, and Pakes 1995) to locational choice, estimating a preference for communities that can be decomposed into the utility for public goods and disutility for high housing costs (see e.g. Bayer, Ferreira, and McMillan 2007, Bayer, Keohane and Timmins 2009, and Tra 2010).

The most fundamental step in this entire body of research is an accurate estimate of the spatial variation in quality-adjusted housing prices. But economists and other analysts have not yet settled on best practices for estimating those indices. In particular, researchers have used a variety of data sources on housing values, including recorded transactions prices, survey data of owner-reported housing values (available from the US Census), tax assessments, and rental prices. Transactions prices often are considered the gold standard, well worth the additional expense of obtaining them, but there has been little actual evidence to justify this presumption. 
A related issue is whether to use micro-level data or aggregate summary statistics. Most studies use micro-level housing data from one of the above sources, but others have relied on aggregate statistics, such as the median housing value in the county or census tract conditioned on community-level housing variables (e.g. Chay and Greenstone 2005, Grainger 2011, Greenstone and Gallagher 2008). Again, there has been little evaluation of these judgments. ${ }^{2}$

Each of these approaches has inherent benefits and shortcomings. In this paper, we evaluate them in two ways. Our first strategy is simple and direct: we construct community-level price indices using a variety of data sources, all of which have been used in the peer-reviewed literature, and compare them to one another. This strategy is one way to gauge how sensitive spatial housing price indices are to data sources, but cannot indicate which data are preferable. Our second strategy employs an "ascending bundles" criterion suggested by Sieg et al. (2002). Using the insights from equilibrium models of locational choice, they note that more expensive communities should be those with better public goods and other locational amenities. Accordingly, those community price indices that best correlate with observed amenities would appear to be most sensible. By this criterion, the "best" index is one that has the best fit when regressed on local amenities. ${ }^{3}$ By a similar logic, these communities will also be inhabited by the richest households. By this criterion, the "best" index is one that has the tightest correlation with average income in the community.

We find that indices based on self-reported values in the US Census are highly correlated with indices based on transactions prices, though the latter are somewhat better correlated with public goods. This finding suggests that while households may provide accurate estimates of the value of their structures (perhaps because of insurance assessments), they do a poorer job of recognizing components of their property values capitalizing local amenities. Indices based on rental prices perform even better when judged by the criterion of correlation with public goods, as well as income. This may be because rents represent current conditions, whereas asset values reflect expected future conditions. Finally, whether based on self-reported asset values or rental

\footnotetext{
${ }^{2}$ See Gamper-Rabindran, Mastromonaco, and Timmins (2011) for one recent discussion of this issue.

${ }^{3}$ Sieg et al. (2002) apply their approach only to functional form and related issues using a single data source. They do not address the question of the type of price information (surveys, transactions, appraisals, or rents), which has been a larger question in the literature. We apply their basic approach to this question.
} 
values, indices that rely on the community's median price, rather than micro data, are not as strongly correlated either with the other indices or with amenities or local incomes. The median price does not appear to aptly represent community-wide conditions.

\section{Approaches to Estimating Community Housing Price Indices}

Perhaps the most fundamental question when it comes to constructing a community-level housing price index is whether to use asset values or rental prices. Often, this choice is determined by the research context, and sometimes researchers make use of both types of data (e.g. Calabrese et al. 2006, Greenstone and Gallagher 2008). Rental prices may be most relevant for short-term service flows, but only if rental contracts adjust rapidly to changes in public goods and taxes. If rents are sticky, they may be out of equilibrium over long periods. Observed asset prices may be more likely to be in equilibrium at a point in time, but reflect anticipated future service flows. ${ }^{4}$

Even when asset values are desired theoretically, in many cases they must be converted to annual user costs (see e.g. Poterba 1992). Concluding that this conversion is too sensitive to assumptions about the opportunity cost of capital and expected capital gains, the US Bureau of Labor Statistics has for many years used rental properties as a proxy for the cost of owneroccupied housing in the Consumer Price Index (see e.g. Gillingham 1983). The BLS's approach has the advantage of side-stepping the imputation of user costs from asset prices. When surveybased data must be used, this approach also has the advantage that households presumably are much more likely to know their monthly rent with accuracy than the market value of their home. ${ }^{5}$ But it has the disadvantage of relying only on rental properties, which may be very different from the owner-occupied housing stock (Glaeser and Gyourko 2007).

When asset values are to be used, they generally come from one of three sources: surveys of owners (e.g. the American Community Survey or American Housing Survey), tax assessments, and actual transactions prices. Each of these sources also has its characteristic advantages and disadvantages. Survey-based data is readily available from the US Census and has been used by Albouy (2010), Bajari and Kahn (2005), Bayer, Keohane, and Timmins (2009),

\footnotetext{
${ }^{4}$ See e.g. the discussion in Greenstone and Gallagher (2008) of these issues and an excellent example of the comparative use that can be made of both types of data.

${ }^{5}$ Calabrese et al. (2006) find that though tax assessments correlate well with self-reports of values at the community level, the same is not true for rental units. However, this may be a consequence of biases in tax assessments or in the user cost formula they use in their exercise.
} 
Greenstone and Gallagher (2008), and many others. This data source is by far the most convenient, if publically available data are used. It also has the advantage of being a representative sample of all homes.

However, one disadvantage with publically available census housing data, at least in the US, is that they are available as micro data only at large geographies, such as a public-use micro area (PUMA), an area with about 100,000 people. One solution to this problem is to use the restricted data, but of course this requires sacrificing the convenience of public data. An alternative approach is to forego the micro data and use aggregate, community-level statistics such as the median home value in a county or census tract (e.g. Chay and Greenstone 2005, Grainger 2011, Greenstone and Gallagher 2008). Most economists would probably agree that, if available, the micro-level data is preferable, for two reasons. First, it makes use of a broader sample of houses. This can be particularly important if only a subset of the distribution of housing quality is affected by a policy (see discussion in Gamper-Rabindran, Mastromonaco, and Timmins 2011). Second, micro data appropriately matches each house's value to its own characteristics, facilitating the conditioning out of observed house-level variables, as with a hedonic regression. But the extent of the tradeoff between accessibility and precision is also still an open question.

Regardless of whether one uses micro or macro data from the Census, there is good reason to question homeowners' ability to assess the value of their home. In early work, Kain and Quigley (1972) found no systematic bias in self reports (though they did find lots of noise). But since that early work, other studies have found that homeowners systematically overstate the values of their homes as compared to observed transactions data. Ilhanfeldt and MartinezVazquez (1986) estimate the overvaluation to be 16 percent; DiPasquale and Somerville (1995) find an effect of about 8-10 percent, and Goodman and Ittner (1992) and Kiel and Zabel (1999) estimate somewhat more modest overvaluations on the order of 5 percent. The gap between selfassessed values and market values may also vary over time, especially during times of large movements in market prices (Anenberg 2011, Kuzmenko and Timmins 2011).

More importantly, for our purposes, Goodman and Ittner (1992), Ihlanfeldt and MartinezVazquez (1986) and Kuzmenko and Timmins (2011) find that these errors in self-reported values are correlated with observables typically included in hedonic regressions, suggesting estimated coefficients in these regressions would be biased. Regressing estimated errors in self assess- 
ments on various characteristics, they find the errors are correlated not only with house-level variables but also neighborhood variables (Ihlanfeldt and Martinez-Vazquez, Kuzmenko and Timmins) or regional dummies (Goodman and Ittner).

However, Kiel and Zabel $(1997,1999)$ have cast doubt on these findings. In particular, Kiel and Zabel (1999) find no such relationship between house- or community-level observables and divergences between self-reported values and observed transactions. Kiel and Zabel (1997) further constructed inter-temporal housing price indices using both data sources, and found little difference in appreciation rates. Interestingly, however, they do find that recent home buyers are the most likely to overestimate the value of their home. ${ }^{6}$ Yet the implications of this intertemporal result for cross-sectional indices is unclear. If households poorly appraise timeinvariant effects, cross-section comparisons may be substantially biased, even while intertemporal indices are accurate. ${ }^{7}$ Needless to say, there appears to be little consensus at this time on the accuracy of owner-reported home values.

Given their innate suspicion of self-assessed values, many economists have preferred to use actual transactions data (e.g. Bishop and Murphy 2011, Black 1999, Davis 2004, Figlio and Lucas 2004, and Sieg et al. 2004). This approach is generally considered the gold standard, since it uses observed, rather than stated, market prices. But this data source does have some disadvantages. Perhaps most importantly, such data are difficult to come by and typically must be purchased at some expense. Moreover, it raises sample selection issues, since the sample of homes that are sold may not be representative of the housing stock as a whole. Clapp and Giaccotto (1992), Gatzlaff and Haurin (1997, 1998), Ihlanfeldt and Martinez-Vazquez (1986), Jud and Seaks (1994), and Kiel and Zabel (1999) all consider the issue of selection bias - again, with

\footnotetext{
${ }^{6}$ See also Follain and Malpezzi (1982) for a similar finding. Kuzmenko and Timmins (2011) find that recent home buyers more correctly predict the values of amenities as well.

${ }^{7}$ For example, suppose in Community 1 in Year 1 the monthly housing costs can be decomposed into a $\$ 600$ housing component (for the structure itself) and a $\$ 600$ community component (for local public goods and amenities). Suppose in Community 2 it is $\$ 400$ and $\$ 200$ respectively. Suppose further that in Year 2 there is pure inflation which increases all these figures by $10 \%$. Finally, suppose that, in their selfreports, households know the housing component exactly in each year, but totally ignore the public goods component. Then in both communities the reported ratio of inter-temporal differences of 1.1:1 would be exactly right (i.e. $660 / 600$ is the same as $1320 / 1200$ and likewise $440 / 400$ is the same as $1100 / 1000$ ). But the ratio of reported cross sectional differences (in either year) would be $3: 2$ while the true value is $2: 1$. In other words, inter-temporal indices based on self-reports would be accurate but cross-sectional indices would not be.
} 
mixed results.

Although less common, some studies also make use of assessed values, usually when attention is restricted to land values (e.g. Walsh 2007). Because homes typically are appraised for tax or mortgage purposes, appraisal data has the advantage of being available on a large sample of homes, suggesting selection may be less of a concern. As experts, assessors are also probably are more accurate than home-owners in their assessments of real estate values. However, they are not infallible. At best, they forecast actual values with some measurement error. At worst, they may systematically ignore spatially varying factors, creating biases in cross-sectional comparisons. Similarly, appraisers and appraisal firms may use different rules across jurisdictions. Ihlanfeldt and Martinez-Vazquez (1986) find that, for the Atlanta metro area, assessor estimates are correct on average, but that they systematically misprice a number of amenities.

\section{Data}

To assess the importance of these judgments about housing data sources, we construct community-level housing price indices using each type of data and then compare them. In particular, we construct cross-sectional housing indices for the Los Angeles metropolitan area (including Los Angeles, Orange, and parts of Riverside, San Bernardino, and Ventura counties) in the year 2000. We define the "communities" of interest as the PUMAs created by the US Census Bureau. Our full data set includes 99 urban PUMAs in the LA area. Figure 1 shows these PUMAs, with the study area shaded. As seen in the figure, in major cities like LA, the PUMAs are reasonably small. Because some PUMAs are discontiguous, we also consider only the subset of 91 contiguous PUMAs in the area.

Defining the communities as PUMAs allows us to compare the full range of approaches from the literature. First, using publically available data from the 2000 decennial census Integrated Public Use Microdata Series (IPUMS), we have micro-level data on individual ownerreported housing values and rents, matched to individual housing characteristics. Naturally, we also have aggregate level data (e.g. median price or rent). Additionally, we have assembled transactional data and assessments for the year 2000 in the area, purchased from SiteXdata (owned by Fidelity National Data Service), which collects and distributes real estate information. These transactions prices are geocoded and can be matched to the PUMAs, allowing a comparison to the survey data at the same level of geography. 
The survey data on home prices from the US Census raises two statistical issues: it is both top coded at $\$ 999,999$ and categorized by price bins (or brackets). We addressed this problem by explicitly modeling the censoring, though we also consider other approaches such as simply giving each observation a value equal to the median of each range. While these issues raise additional complications in the comparisons, Kiel and Zabel (1997) find that top coding and bracketing have little impact on intertemporal price indices. Our results confirm their finding: We also find little sensitivity to this issue in our cross-sectional indices.

The data on tax assessments raises another issue. Since passage of Proposition 13, California has used an acquisition-value tax system in which tax assessments are tied to the most recent sale, with upward adjustments capped at 2 percent per year (see O'Sullivan, Sexton, and Sheffrin 1995). Consequently, assessment-based indices in this application ought to be quite close to the transactions-based indices. Accordingly, the results for the assessment-based index are of less interest in this application than they might be in other parts of the country.

Each data set includes data on housing structures that can be used to hedonically adjust each community house index for the size and quality of dwelling units. The US Census data reports the number of bedrooms, number of other rooms, ordinal data on lot size, a dummy variable for condominiums, and dummy variables for natural gas connections and various heating sources. For rental units, the Census data also includes an indicator for whether meals are included and various ordinal variables for the number of units in the building. The transactions and tax assessment data from SiteX is limited to single-family units, consistent with most studies using such data. It includes the number of bedrooms, number of bathrooms, cardinal data on lot size, dwelling unit size, and a dummy variable for a swimming pool. These data are summarized in Table 1.

A final issue raised by these data is the fact that these house-level controls are not perfectly overlapping across data sets. One perspective on this issue is that, inevitably, when choosing data sources researchers are in fact committing themselves to using certain control variables, and these differences are an inherent part of the choice. From this point of view, these differences in the data are as relevant as any other and should be factored into any comparison. Another perspective is that differences in available hedonic control variables may cloud inference about the dependability of the price data itself. From this point of view, these differences should be 
factored out. As discussed below, we consider both perspectives, hedonically adjusting the price indices for either all available controls or alternatively only for those that are common to all datasets. We find little sensitivity of the results to this choice.

Finally, in addition to the house-level data, we gathered community level data on public goods and other amenities. These include school quality, commute times, air quality, and proximity to the coast. For school quality, we use the $9^{\text {th }}$ grade Standardized Testing and Reporting (STAR) test, summing the math and reading scores. ${ }^{8,9}$ For commute times, we used the average time reported in the US Census, by PUMA. For air quality, we gathered ozone data from the US EPA at monitors in the five-county LA area and all bordering counties. At each monitor, we collected the average annual number of exceedences of the 1-hour ozone standard from 19982000. We then imputed these values to each census tract, using an inverse-distance weighted average of the two nearest monitors, and then aggregated tracts up to PUMAS using housing units as weights. And for the coastal variable, we simply assigned a coastal indicator variable equal to one if a PUMA borders the Pacific Ocean. Table 2 provides summary statistics of these variables.

\section{Methods and Results}

For the microdata-based indices, we model housing prices as a log-linear function of housespecific structural parameters $\mathbf{x}$ and community fixed effects $\alpha$. That is, for house $h$ in community $c$ using data source and data treatment $d$, prices are modeled as $\ln P_{h c d}=\alpha_{c d}+\boldsymbol{\beta}_{d}^{\prime} \mathbf{x}_{h c d}+\varepsilon_{h c d}$

For each of our base or "preferred" models, the vector $\mathbf{x}$ includes all the available regressors listed in Table 1 for each data source $d$, with age entered flexibly through a set of nine dummy variables. Following the standard approach in the literature, we then compute the price index for Community $c$ from the community fixed effect, as $\exp \left(\alpha_{c d}\right)$, and renormalize the indices on $(0,1)$

\footnotetext{
${ }^{8}$ Additionally, we considered math and reading scores as separate variables, but could not reject the hypothesis that the coefficient on each was identical. Accordingly, we simply summed the two scores.

${ }^{9}$ Because geo-coded boundary maps were not available at the school level, we impute test scores to each census block group by assigning it to the nearest high school within its school district. We then aggregated up to the PUMA.
} 
for each data source/treatment $d .^{10}$

For the median-based indices, we have only one observation per community. In this case, we estimate the following model:

$\ln \left(\operatorname{median} P_{c d}\right)=\alpha_{d}+\boldsymbol{\beta}_{d}^{\prime} \overline{\mathbf{x}}_{c d}+\varepsilon_{c d}$

where $\overline{\mathbf{x}}_{c d}$ is the mean value of the structural variables in community $c$ for data source $d$. Note $\overline{\mathbf{x}}_{c d}$ may include the mean values of dummy variables, e.g., for age categories, giving the proportion of the housing stock falling in each category; in this way, other summary statistics besides the mean may be captured. Then the price index is computed from the community-level residual as $\exp \left(\alpha_{d}+\varepsilon_{c d}\right)$.

Are Cross Sectional Price Indices Sensitive to Data Sources?

Our first set of results addresses the question of the sensitivity of community housing price indices to the data used. To address this question, we simply compute the correlation matrix of all the price indices we have considered. These results are shown in Table 3. The table is divided into six sections, each corresponding to one of the six main data sources: transactions prices, micro-based indices of self-reported asset prices, median-based indices of self-reported asset prices, tax assessments, micro-based indices of rental prices, and median-based indices of rental prices. The first row/column in each section corresponds to our preferred approach for using each data source. In these preferred models, we control for all available hedonic variables and, for the self-reported asset prices, we account for the binning and top-coding of the data using a generalized Tobit regression. The other rows/columns in each section correspond to alternative treatments of the data, discussed in detail below.

Comparing for now only the preferred models in the first rows/columns of each section to one another, we first note that indices based on self-reported values from the US Census are quite close to transactions data, a result consistent with Kiel and Zabel's (1997) comparison of inter-temporal price indices. The correlations between the indices using transactions prices and self-reported values is 0.96. The relationship is depicted in Panel A of Figure 2. These results would appear to justify the use of more easily obtainable Census data as a proxy for expensive

\footnotetext{
${ }^{10}$ An alternative approach would predict the price of a house with specific characteristics in each community, allowing $\boldsymbol{\beta}$ to vary and omitting the fixed effect (see e.g. Malpezzi, Chun, and Green 1998, Sieg et al. 2002).
} 
transactions data - as long as micro-level data is available with which to hedonically adjust for house size. However, as we will see below, the transactions data are more tightly correlated with public goods.

Moreover, this picture changes when we consider the median self-assessed price in the community. The correlation between the median-price self-report index and the transactionbased index is only 0.54 . Significantly, even the correlation between the median-based selfreported index and the micro-based self-reported index is only 0.60 (Panel B of Figure 2), suggesting that relying on the median price substantially changes the pattern of cross-sectional prices regardless of the actual source of those prices.

Second, in this application to Los Angeles, indices based on transactions data are very close to those based on tax assessments. The correlation between the indices using these two data sources is above 0.99. This tight correlation is depicted in Panel C of Figure 2. As noted previously, this is not surprising in our application to California, where tax assessments are formally based on past transactions prices.

Next, we find that indices based on rental prices deviate somewhat from those using asset values. The correlation of rental prices with transactions prices is 0.86 (depicted in Panel D of Figure 2), while the correlation with self-reported asset values is only about 0.80 (Panel E). Again, though, the pattern is very different for the median-based index using rental prices. Its correlation with the micro-based rental index, depicted in Panel F of Figure 2, is only 0.46 . In fact, its correlation with the median-based asset-price index is almost as high (0.44), suggesting the use of the median per se drives the variation as much as the type of price.

Turning now to the variants of these indices within each group, we find the results are not at all sensitive to the treatment of the data. In particular, for any of the data sources, confining the hedonic price model to a parsimonious set of regressors common to both the census and transactions data sources makes little difference. ${ }^{11}$ The correlations with these parsimonious indices and our preferred indices are all 0.99. Similarly, the correlations across data sources change only slightly when we confine the comparison to a common set of regressors. For exam-

\footnotetext{
${ }^{11}$ The "parsimonious" models restrict the hedonic model to only bedrooms, other rooms (census) or bathrooms (SiteX), the measures of lot size, and age. Of course, the implication of omitted variables for predicting prices is ambiguous and different than their implication for obtaining unbiased estimates of regression parameters (see Malpezzi, Chun, and Green 1998 for discussion in the housing context).
} 
ple, the correlation between the transactions-price index and the self-assessment index remains about 0.96 , whereas the correlation between the transaction-price index and rent index falls slightly from 0.86 to 0.82 . Additionally, for the self-reported data, ignoring the binning and topcoding of the census data makes little difference. ${ }^{12}$ Correlations involving these types of comparisons also are all over 0.99 . We also considered restricting the analysis to the 91 contiguous PUMAs. Again, that restriction made little difference, with each of the correlations virtually unchanged.

In summary, it appears that the asset-based price indices using micro data all have very similar cross-sectional patterns, regardless of the data source (transactions, census self reports, tax assessments). Rent-based price indices give a somewhat different pattern. And the greatest outliers are the median-based indices, whether based on asset prices or rents. However, simply noting such similarities and differences in the correlations cannot speak to which approach does a better job of reflecting patterns in spatial amenities and demographics. We consider this question in the following section.

\section{Relationship with Spatial Amenities}

Economic intuition suggests that spatial amenities should be capitalized into property values. As Sieg et al. (2002) argue, this intuition suggests a criterion for evaluating spatially delineated price indices: better price indices should be more closely correlated with public goods and incomes. Sieg et al. apply this logic to the computational formulae for computing indices (simple hedonics, imputation methods, etc.). In this section, we apply their logic to the various data sources that researchers have traditionally used.

Table 4 shows the relationship between each of the indices we have considered and a set of important spatial amenities. The amenities include the average ninth grade test score on the California Star test, the average commute time to work, the number of days exceeding the national 1-hour ozone standard, and a dummy variable for whether the community borders the coast. Columns 1-3 of the table shows simple correlations between each index and each of these variables, omitting the coastal dummy. (Because of their close connection to transactions-based price indices, we now omit the indices based on tax assessments.) The table shows that all the

\footnotetext{
${ }^{12}$ In this variant, we simply run OLS after assigning a price equal to the midpoint of the bin and, for the top-coded observations, a price of $\$ 999,999$.
} 
indices have strong pairwise correlations with at least some of the amenities, although the strength of the correlations is notably lower for the median-based indices. However, because the various indices are more or less correlated with different amenities, it is difficult to make any conclusions about the relative performance of the indices without first deciding which amenities are of more interest.

Accordingly, we next regress each price index on the entire bundle of four amenities. The next four columns of Table 4 show the coefficients from this regression (the constant term is not shown). The fifth column shows the $\mathrm{R}^{2}$ from this regression. As a measure of fit, the $\mathrm{R}^{2}$ of the regression represents a gauge of the correlation between the price indices and the spatial amenities, taken as a bundle. As an alternative indicator of fit, the last three columns of the table show the number of normalized rank violations between the price index and the index of public goods as computed from the respective regression (the proportion of possible pairwise comparisons that are off in rank by 1,5 , or 10 places). When the data are sorted by their price rank, the rank violations are computed as follows:

Normalized Rank Violations $=\frac{2}{N(N-1)} \sum_{i=2}^{N} \sum_{j=1}^{i-1} 1\left[\right.$ Price Rank $_{j} \geq$ Amenities Rank $\left._{i}+k\right]$ for $k \in\{0,4,9\}$.

Comparing the $\mathrm{R}^{2} \mathrm{~s}$, we again find that, within data sources, there is little difference across methods of computing the indices. However, there are substantial differences across data sources. Consider first the indices based on market transactions relative to those based on selfreported values. As shown in Table 3 we found those two sets of indices were highly correlated (with a correlation of 0.96 ). From this, one might conclude that it makes little difference which data source is used. However, we get a very different impression when we compare the relationship between each with the set of spatial amenities. Here, we find that the indices based on market transactions perform better. When regressed on public goods, the hedonic index based on market transactions has an $\mathrm{R}^{2}$ of 0.53 , compared to 0.42 for the hedonic index based on selfreported values.

Apparently, though the two indices are tightly correlated, and thus based on some common factors, a substantial portion of the remaining residual can be accounted for by public goods. To confirm this intuition, we first "partial out" that portion of the transactions-price index 
that can be explained by the self-reported index. We then regress the remaining residual on the index of spatial amenities. The latter regression has an $\mathrm{R}^{2}$ of 0.18 , and a joint test of the significance of the amenities has a $p$-value of $<0.01$. In other words, it appears that households do not fully account for cross-sectional variation in public goods and spatial amenities when estimating the value of their own home.

The indices based on rental prices perform even better than the market transactions indices, based on the criterion of fit with spatial amenities. The $\mathrm{R}^{2}$ of these regressions are in the neighborhood of 0.68 , substantially better than the values of 0.53 and 0.42 for the transactionsbased and self-report-based indices respectively. As discussed previously, in a world of no transactions costs, rents theoretically would be expected to better reflect current levels of amenities, in contrast to asset values which reflect the expected future stream of amenities, which in turn are unobserved by the analyst. However, this might not be true if rents do not fully adjust to current conditions because of transactions costs, whereas observed asset prices of property (which are conditional on the property selling) do reflect current conditions. Our results suggest that the former effect dominates, so rents better reflect current conditions than asset prices. Because current conditions are in principle observed by the analyst but the future conditions expected by market participants is not observed, this is a strong argument for using rents rather than asset values in Tiebout-like applications in the public economics literature.

A final result of interest is that neither the median-based index of self-reported asset values nor the median-based index of rental prices performs very well by this criterion. The $\mathrm{R}^{2}$ of the regressions of these indices on spatial amenities is only 0.10 and 0.15 respectively, and, with the exception of air quality, the individual coefficients on amenities are statistically insignificant. These median-based price indices also have more rank violations with the amenities index than the other price indices. It appears that relying on the median price, rather than making use of micro data, entails a substantial loss of information. ${ }^{13}$

\footnotetext{
${ }^{13}$ Gamper-Rabindran, Mastromonaco, and Timmins (2011) make a related argument that only a portion of the housing-price distribution may be affected by an amenity, especially if that amenity is located at a discrete point in space. They consider the example of superfund sites, which tend to be located in neighborhoods with the lowest housing costs. In such cases, the "median home" may not reflect the (dis)amenity, whereas prices in the lower part of the distribution might. However, all neighborhoods likely would benefit from a marginal improvement in their public schools, commute time, and air pollution, the amenities which we consider.
} 


\section{Relationship with Income}

Just as economic intuition suggests that prices should be correlated with local amenities, it also suggests that it is the richer households who will pay these higher prices to enjoy the amenities. In models of vertically differentiated communities, this relationship is known as the "ascending bundles" property (e.g. Epple and Sieg 1999). This property provides an additional criterion: just as a good price index of community real estate prices (consistent with economic theory) should be correlated with an index of local amenities, so too should it be correlated with average income in the community. We consider this criterion next, using both simple correlations and the normalized rank violations. The results are displayed in Table 5 and Figure 3. The results are similar to those using the criterion of local amenities. The transactions-based indices and the self-report-based indices perform reasonably well and similar to each other, each having a correlation with incomes of about 0.68 (Panels A and B of Figure 3). The rent-based indices again perform somewhat better, with a correlation with income of about 0.83 (Panel D). Finally, both median-based indices again perform much worse, with correlations with income of only 0.28 and 0.29 (Panels C and E).

\section{Conclusions}

The capitalization of local amenities into real estate values plays a crucial role in many applications in public, urban, and environmental economics. It goes almost without saying that an accurate measure of real estate values is a crucial component of such empirical applications. We compared a variety of measures used in the literature by constructing spatial price indices for 99 communities in the Los Angeles area. We considered the correlation among different price indices, as well as the extent to which they reflect differences in spatial amenities and household income across communities.

We find that indices based on self-reported values in the US Census are highly correlated with indices based on transactions prices. Indices based on median values, rather than micro data, appear as outliers in the comparisons. When considering the extent to which the indices capture spatial differences in contemporaneous amenities and income, indices based on rents appear to perform the best, with transactions prices and self-reports coming in second and third. Indices based on median values or rents perform the worst by these criteria. 
These results suggest that, despite their potential to be sticky over time, rents represent current conditions better than asset values, which reflect expected future conditions. Among asset-based approaches, actual transactions prices appear to better capture local amenities than do self-reports, perhaps because households do not consider these factors. Nevertheless, the two measures are closely correlated, and so self-reports may be a practicable alternative in some cases. 


\section{References}

Albouy, David. 2010. "What Are Cities Worth? Land Rents, Local Productivity, and the Capitalization of Amenity Values." Mimeo.

Anenberg, Elliot. 2011. "Uncertainty, Learning, and the Value of Information in the Residential Real Estate Market." Mimeo.

Bajari, Patrick, and Matthew E. Kahn. 2005. "Estimating Housing Demand with an Application to Explaining Racial Segregation in Cities." Journal of Business and Economic Statistics 23: $20-33$.

Bayer, Patrick, Fernando Ferreira and Robert McMillan. 2007 "A Unified Framework for Measuring Preferences for Schools and Neighborhoods." Journal of Political Economy 115: 588-638.

Bayer, Patrick, Nathaniel Keohane, and Christopher Timmins. 2009. "Migration and Hedonic Valuation: The Case of Air Quality." Journal of Environmental Economics and Management 58: 1-14.

Berry, Steven, James Levinsohn, and Ariel Pakes. 1995. "Automobile Prices in Market Equilibrium." Econometrica 63: 841-890.

Bishop, Kelly C., and Alvin D. Murphy. 2011. "Estimating the Willingness to Pay to Avoid Violent Crime: A Dynamic Approach." American Economic Review Papers and Proceedings 101: 625-9.

Black, Sandra. 1999. "Do Better Schools Matter? Parental Valuation of Elementary Education." Quarterly Journal of Economics 114: 578-99.

Blomquist, Glenn C., Mark C. Berger, and John P. Hoehn. 1988. "New Estimates of Quality of Life in Urban Areas." American Economic Review 78: 89-107.

Calabrese, Stephen, Dennis Epple, Thomas Romer, and Holger Sieg. 2006. "Local Public Good Provision: Voting, Peer Effects, and Mobility." Journal of Public Economics 90: 95981.

Chay, Kenneth Y., and Michael Greenstone. 2005. "Does Air Quality Matter? Evidence from the Housing Market." Journal of Political Economy 115: 376-424.

Clapp, John M., and Carmelo Giaccotto. 1992. "Estimating Price Indices for Residential Property: A Comparison of Repeat Sales and Assessed Value Methods." Journal of the American Statistical Association 87: 300-306.

Davis, Lucas W. 2004. "The Effect of Health Risks on Housing Values: Evidence from a Cancer Cluster." American Economic Review 94: 1693-1704.

DiPasquale, Denise, and C. Tsuriel Somerville. 1995. "Do House Price Indices Based on Trans- 
acting Units Represent the Entire Stock? Evidence from the American Housing Survey." Journal of Housing Economics 4: 195-229.

Epple, Dennis, and Holger Sieg. 1999. "Estimating Equilibrium Models of Local Jurisdiction." Journal of Political Economy 107: 645-81.

Figlio, David N. and Maurice E. Lucas. 2004. "What's in a Grade? School Report Cards and the Housing Market." American Economic Review 94: 591-604.

Follain, James R., and Stephen Malpezzi. 1981. "Are Occupants Accurate Appraisers?" The Review of Public Data Use 9: 47-55.

Gamper-Rabindran, Shanti, Ralph Mastromonaco, and Christopher Timmins. 2011. "Valuing the Benefits of Superfund Site Remediation: Three Approaches to Measuring Localized Externalities." NBER Working Paper 16655. http://www.nber.org/papers/w16655.

Gatzlaff, Dean H., and Donald R. Haurin. 1997. "Sample Selection Bias and Repeat-Sales Index Estimates." Journal of Real Estate Finance and Economics 14: 33-50.

Gatzlaff, Dean H., and Donald R. Haurin. 1998. "Sample Selection and Biases in Local House Value Indices." Journal of Urban Economics 43: 199-222.

Gillingham, Robert. 1983. "Measuring the Cost of Shelter for Homeowners: Theoretical and Empirical Considerations." Review of Economics and Statistics 65: 254-65.

Glaeser, Edward, and Joseph Gyourko. 2007. "Arbitrage in Housing Markets." NBER Working Paper 13704.

Goodman, John L., and John B. Ittner. 1992. "The Accuracy of Home Owners' Estimates of House Value." Journal of Housing Economics 2: 339-57.

Grainger, Corbett A. 2011. "The Distributional Effects of Pollution Regulations: Do Renters Fully Pay for Cleaner Air?" Mimeo. Accessed at http://www.aae.wisc.edu/ cagrainger/Renters_June30_2011.pdf

Greenstone, Michael, and Justin Gallagher. 2008. "Does Hazardous Waste Matter? Evidence from the Housing Market and the Superfund Program." Quarterly Journal of Economics 123: 951-1003.

Ihlanfeldt, Keith R., and Jorge Martinez-Vazquez. 1986. "Alternative Value Estimates of Owner-Occupied Housing: Evidence on Sample Selection Bias and Systematic Errors." Journal of Urban Economics 20: 356-369.

Jud, G. Donald, and Terry G. Seaks. 1994. "Sample Selection Bias in Estimating Housing Sales Prices." Journal of Real Estate Research 9: 289-98.

Kain, John F., and John M. Quigley. 1972. "Note on Owner's Estimate of Housing Value." Journal of the American Statistical Association 67: 803-6. 
Kiel, Katherine A., and Jeffrey E. Zabel. 1997. "Evaluating the Usefulness of the American Housing Survey of Creating House Price Indicies." Journal of Real Estate Finance and Economics 14: 189-202.

Kiel, Katherine A., and Jeffrey E. Zabel. 1999. "The Accuracy of Owner Provided House Values: The 1978-1991 American Housing Survey." Real Estate Economics 27: 263-8.

Kuminoff, Nicolai V. 2011. "An Intraregional Model of Housing and Labor Markets for Estimating the General Equilibrium Benefits of Large Changes in Public Goods." Mimeo.

Kuminoff, Nicolai V., V. Kerry Smith, and Christopher Timmins. 2010. "The New Economics of Equilibrium Sorting and its Transformation Role for Policy Evaluation." NBER Working Paper 16349.

Kuzmenko, Tatyana, and Christopher Timmins. 2011. "Persistence in Housing Wealth Perceptions: Evidence from the Census Data." Mimeo.

Malpezzi, Stephen, Gregory H. Chun, and Richard K. Green. 1998. "New Place-to-Place Housing Price Indexes for US Metropolitan Areas, and their Determinants." Real Estate Economics 26: 235-74.

Oates, Wallace E. 1969. "The Effects of Property Taxes and Local Public Spending on Property Values: An Empirical Study of Tax Capitalization and the Tiebout Hypothesis. Journal of Political Economy 77: 957-71.

O'Sullivan, Arthur, Terri A. Sexton, and Steven M. Sheffrin. 1995. Property Taxes and Tax Revolts: The Legacy of Proposition 13. Cambridge, UK: Cambridge University Press.

Palmon, Oded, and Barton A. Smith. 1998. "New Evidence on Property Tax Capitalization." Journal of Political Economy 106: 1099-1111.

Palmquist, Raymond B. 2004. "Property Value Models." In Karl-Göran Mäler and Jefferey Vincent, eds., Handbook of Environmental Economics, volume 2. Amsterdam: Elsevier North Holland.

Poterba, James. 1992. "Taxation and Housing: Old Questions, New Answers." American Economic Review Papers and Proceedings 82: 237-242.

Ridker, Ronald G., and John A. Henning. 1967. "The Determinants of Residential Property Values with Special Reference to Air Pollution." Review of Economics and Statistics 49: $246-57$.

Sieg, Holger, V. Kerry Smith, H. Spencer Banzhaf, and Randy Walsh. 2002. "Interjurisdictional Housing Prices in Locational Equilibrium." Journal of Urban Economics, 52: 131-53.

Sieg, Holger, V. Kerry Smith, H. Spencer Banzhaf, and Randy Walsh. 2004. "Estimating the General Equilibrium Benefits of Large Changes in Spatially Delineated Public Goods." 
International Economic Review 45: 1047-77.

Smith, V. Kerry, and Ju-Chin Huang. 1995. "Can Markets Value Air Quality? A Meta-Analysis of Hedonic Property Value Models." Journal of Political Economy 103: 209-27.

Tra, Constant. 2010. "A Discrete Choice Equilibrium Approach to Valuing Large Environmental Changes." Journal of Public Economics 94: 183-96.

Walsh, Randall P. 2007. "Endogenous Open Space Amenities in a Locational Equilibrium." Journal of Urban Economics 61: 319-44. 
Table 1: Mean Values of Hedonic Variables

\begin{tabular}{|c|c|c|c|c|}
\hline \multirow[b]{2}{*}{ Variable } & \multirow{2}{*}{$\begin{array}{c}\begin{array}{c}\text { Transactions } \\
\text { Data }\end{array} \\
\text { Owner- } \\
\text { Occupied Units } \\
\end{array}$} & \multirow{2}{*}{$\begin{array}{c}\begin{array}{c}\text { Assessment } \\
\text { Data }\end{array} \\
\text { Owner- } \\
\text { Occupied Units }\end{array}$} & \multicolumn{2}{|c|}{ Census Data } \\
\hline & & & $\begin{array}{c}\text { Owner- } \\
\text { Occupied Units }\end{array}$ & $\begin{array}{c}\text { Renter- } \\
\text { Occupied Units }\end{array}$ \\
\hline \# Observations & 109,140 & 83,635 & 339,469 & 237,306 \\
\hline Observed Sale Price & $\$ 292,448$ & -- & -- & -- \\
\hline Assessed Value & -- & $\$ 324,281$ & -- & -- \\
\hline Self-Reported Value & -- & -- & $\$ 273,625$ & -- \\
\hline Monthly Rent & -- & -- & -- & $\$ 774$ \\
\hline Bedrooms & 3.208 & 3.204 & 3.119 & 1.920 \\
\hline Other rooms & -- & -- & 2.877 & 1.979 \\
\hline Bathrooms & 2.091 & 2.097 & -- & -- \\
\hline $\begin{array}{l}\text { House size } \\
\text { (square feet) }\end{array}$ & 1732 & 1732 & -- & -- \\
\hline $\begin{array}{l}\text { Lot more than } 9 \text { acres } \\
(0 / 1)\end{array}$ & -- & -- & 0.042 & 0.021 \\
\hline Lot size (acres) & 0.2043 & 0.2039 & -- & -- \\
\hline Age & 39.16 & 39.67 & 34.94 & 33.65 \\
\hline Condo $(0 / 1)$ & -- & -- & 0.045 & -- \\
\hline Natural gas $(0 / 1)$ & -- & -- & 0.887 & 0.741 \\
\hline Electric heat $(0 / 1)$ & -- & -- & 0.097 & 0.236 \\
\hline Solar heat $(0 / 1)$ & -- & -- & 0.001 & 0.004 \\
\hline BTLP gas (0/1) & -- & -- & 0.010 & 0.016 \\
\hline Wood heat $(0 / 1)$ & -- & -- & 0.003 & 0.002 \\
\hline Swimming pool $(0 / 1)$ & 0.1807 & 0.1827 & -- & -- \\
\hline Meal included (0/1) & -- & -- & -- & 0.008 \\
\hline 2 unit structure $(0 / 1)$ & 0 & 0 & 0 & 0.044 \\
\hline $\begin{array}{l}3-4 \text { unit structure } \\
(0 / 1)\end{array}$ & 0 & 0 & 0 & 0.127 \\
\hline $\begin{array}{l}5-9 \text { unit structure } \\
(0 / 1)\end{array}$ & 0 & 0 & 0 & 0.126 \\
\hline $\begin{array}{l}10-19 \text { unit structure } \\
(0 / 1)\end{array}$ & 0 & 0 & 0 & 0.110 \\
\hline $\begin{array}{l}20-49 \text { unit structure } \\
(0 / 1)\end{array}$ & 0 & 0 & 0 & 0.100 \\
\hline $\begin{array}{l}50+\text { unit structure } \\
(0 / 1)\end{array}$ & 0 & 0 & 0 & 0.113 \\
\hline
\end{tabular}


Table 2: Values of Locational Amenities

\begin{tabular}{lcccc}
\hline \hline & \multicolumn{5}{c}{ Standard } \\
Variable & Mean & Deviation & Minimum & Maximum \\
\hline Test Score & 1386 & 26.13 & 1333 & 1446 \\
Commute Time & 28.83 & 3.082 & 17.8 & 36.4 \\
Ozone exceedences & 3.836 & 4.879 & 0 & 23.05 \\
Coastal (0/1) & 0.1111 & -- & 0 & 1 \\
\hline \hline
\end{tabular}

Statistics based on 99 observations (one per community). 
Table 3. Correlation Coefficients among Community Price Indices

\begin{tabular}{|c|c|c|c|c|c|c|c|c|c|c|c|}
\hline & 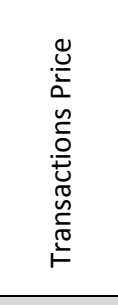 & 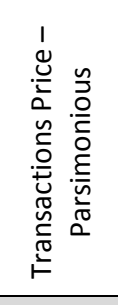 & 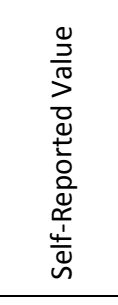 & 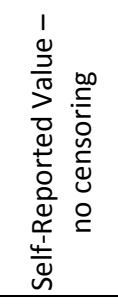 & 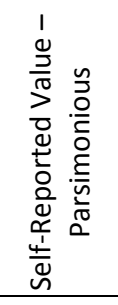 & 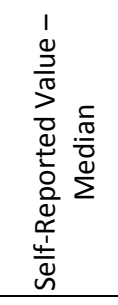 & 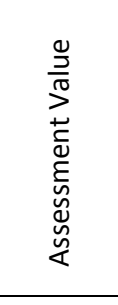 & 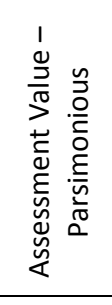 & 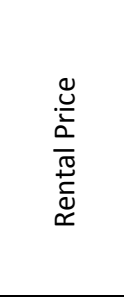 & 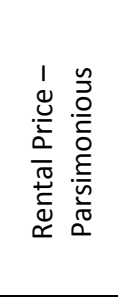 & 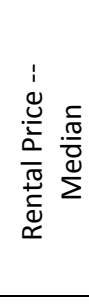 \\
\hline Transactions Price & 1 & & & & & & & & & & \\
\hline $\begin{array}{l}\text { Transactions Price } \\
\text { - Parsimonious }\end{array}$ & 0.996 & 1 & & & & & & & & & \\
\hline $\begin{array}{l}\text { Self-Reported } \\
\text { Value }\end{array}$ & 0.956 & 0.966 & 1 & & & & & & & & \\
\hline $\begin{array}{l}\text { Self-Reported } \\
\text { Value - } \\
\text { Parsimonious } \\
\text { Self-Reported } \\
\text { Value - Ignoring } \\
\text { censoring }\end{array}$ & 0.951 & 0.962 & 0.999 & 0.998 & 1 & & & & & & \\
\hline $\begin{array}{l}\text { Self-Reported } \\
\text { Value - Median }\end{array}$ & 0.543 & 0.542 & 0.598 & 0.610 & 0.598 & 1 & & & & & \\
\hline Assessment Value & 0.998 & 0.993 & 0.955 & 0.950 & 0.963 & 0.545 & 1 & & & & \\
\hline $\begin{array}{l}\text { Assessment Value } \\
\text { - Parsimonious }\end{array}$ & 0.993 & 0.998 & 0.966 & 0.962 & 0.971 & 0.545 & 0.995 & 1 & & & \\
\hline Rental Price & 0.861 & 0.842 & 0.800 & 0.791 & 0.809 & 0.371 & 0.849 & 0.829 & 1 & & \\
\hline $\begin{array}{l}\text { Rental Price - } \\
\text { Parsimonious }\end{array}$ & 0.84 & 0.818 & 0.776 & 0.767 & 0.786 & 0.360 & 0.826 & 0.803 & 0.997 & 1 & \\
\hline $\begin{array}{l}\text { Rental Price - } \\
\text { Median }\end{array}$ & 0.402 & 0.372 & 0.346 & 0.344 & 0.352 & 0.439 & 0.410 & 0.377 & 0.455 & 0.472 & 1 \\
\hline
\end{tabular}


Table 4. Relationships between Community Price Indices and Spatial Amenities

\begin{tabular}{|c|c|c|c|c|c|c|c|c|c|c|c|}
\hline & \multicolumn{3}{|c|}{ Simple Correlations } & \multicolumn{4}{|c|}{$\begin{array}{c}\text { Regression Coefficients } \\
\text { (Standard Errors in Parentheses) }\end{array}$} & \multirow[b]{2}{*}{$\mathrm{R}^{2}$} & \multicolumn{3}{|c|}{$\begin{array}{c}\text { Normalized Rank Violations } \\
\text { with Amenities Index }\end{array}$} \\
\hline & $\begin{array}{l}\text { Test } \\
\text { Score }\end{array}$ & $\begin{array}{l}\text { Commute } \\
\text { Time }\end{array}$ & Ozone & Test Score & $\begin{array}{l}\text { Commute } \\
\text { Time }\end{array}$ & Ozone & $\begin{array}{c}\text { Coastal } \\
\text { Community }\end{array}$ & & 1 Place & 5 Places & $\begin{array}{c}10 \\
\text { Places }\end{array}$ \\
\hline Transactions Price & 0.508 & -0.384 & -0.466 & $\begin{array}{l}0.321 * * * \\
(0.051)\end{array}$ & $\begin{array}{c}-1.019 * * \\
(0.453)\end{array}$ & $\begin{array}{c}-1.597 * * * \\
(0.195)\end{array}$ & $\begin{array}{l}12.034^{*} \\
(6.488)\end{array}$ & 0.528 & 0.13 & 0.10 & 0.07 \\
\hline $\begin{array}{l}\text { Transactions Price - } \\
\text { Parsimonious }\end{array}$ & 0.496 & -0.358 & -0.442 & $\begin{array}{l}0.332 * * * \\
(0.054)\end{array}$ & $\begin{array}{l}-0.918 * \\
(0.466)\end{array}$ & $\begin{array}{c}-1.596 * * * \\
(0.199)\end{array}$ & $\begin{array}{l}11.113 \\
(6.748)\end{array}$ & 0.483 & 0.14 & 0.11 & 0.07 \\
\hline Self-Reported Value & 0.447 & -0.317 & -0.443 & $\begin{array}{l}0.254 * * * \\
(0.043)\end{array}$ & $\begin{array}{l}-0.552 \\
(0.369)\end{array}$ & $\begin{array}{c}-1.379 * * * \\
(0.175)\end{array}$ & $\begin{array}{c}6.388 \\
(4.953)\end{array}$ & 0.420 & 0.14 & 0.10 & 0.08 \\
\hline $\begin{array}{l}\text { Self-Reported Value - } \\
\text { Parsimonious }\end{array}$ & 0.440 & -0.306 & -0.439 & $\begin{array}{c}0.251 * * * \\
(0.044)\end{array}$ & $\begin{array}{l}-0.501 \\
(0.366)\end{array}$ & $\begin{array}{c}-1.368 * * * \\
(0.174)\end{array}$ & $\begin{array}{c}6.296 \\
(4.929)\end{array}$ & 0.409 & 0.14 & 0.10 & 0.08 \\
\hline $\begin{array}{l}\text { Self-Reported Value - } \\
\text { Ignoring Censoring }\end{array}$ & 0.462 & -0.324 & -0.453 & $\begin{array}{l}0.281^{* * * *} \\
(0.047)\end{array}$ & $\begin{array}{l}-0.598 \\
(0.398)\end{array}$ & $\begin{array}{c}-1.504 * * * \\
(0.185)\end{array}$ & $\begin{array}{c}6.929 \\
(5.294)\end{array}$ & 0.442 & 0.14 & 0.10 & 0.08 \\
\hline $\begin{array}{l}\text { Self-Reported Value - } \\
\text { Median }\end{array}$ & 0.110 & -0.035 & -0.263 & $\begin{array}{c}0.048 \\
(0.055)\end{array}$ & $\begin{array}{c}0.385 \\
(0.434)\end{array}$ & $\begin{array}{c}-0.809 * * * \\
(0.223)\end{array}$ & $\begin{array}{c}7.071 \\
(5.529)\end{array}$ & 0.103 & 0.30 & 0.26 & 0.22 \\
\hline Rental Price & 0.686 & -0.381 & -0.439 & $\begin{array}{c}0.535 * * * \\
(0.047)\end{array}$ & $\begin{array}{l}-0.772 * \\
(0.448)\end{array}$ & $\begin{array}{c}-1.782 * * * \\
(0.228)\end{array}$ & $\begin{array}{c}4.278 \\
(4.812)\end{array}$ & 0.682 & 0.12 & 0.09 & 0.06 \\
\hline $\begin{array}{l}\text { Rental Price - } \\
\text { Parsimonious }\end{array}$ & 0.703 & -0.375 & -0.428 & $\begin{array}{c}0.544 * * * \\
(0.047)\end{array}$ & $\begin{array}{l}-0.706 \\
(0.438)\end{array}$ & $\begin{array}{c}-1.725 * * * \\
(0.232)\end{array}$ & $\begin{array}{c}4.357 \\
(4.664)\end{array}$ & 0.696 & 0.12 & 0.09 & 0.06 \\
\hline Rental Price - Median & 0.142 & -0.224 & -0.344 & $\begin{array}{c}0.067 \\
(0.068)\end{array}$ & $\begin{array}{l}-0.641 \\
(0.683)\end{array}$ & $\begin{array}{c}-1.119 * * * \\
(0.370)\end{array}$ & $\begin{array}{c}3.940 \\
(7.180)\end{array}$ & 0.153 & 0.26 & 0.22 & 0.18 \\
\hline
\end{tabular}

All models based on 99 observations (one observation per community).

Robust standard errors in parentheses.

***Statistically significant at the $1 \%$ level; **5\% level; *10\% level. 


\begin{tabular}{lcccc} 
& \multicolumn{3}{c}{ Normalized Rank Violations } \\
& $\begin{array}{c}\text { Simple } \\
\text { Correlation }\end{array}$ & 1 Place & 5 Places & 10 Places \\
\hline $\begin{array}{l}\text { Transactions Price } \\
\begin{array}{l}\text { Transactions Price - } \\
\text { Parsimonious }\end{array}\end{array}$ & 0.68 & 0.19 & 0.15 & 0.10 \\
\hline $\begin{array}{l}\text { Self-Reported Value } \\
\text { Self-Reported Value - }\end{array}$ & 0.67 & 0.19 & 0.15 & 0.11 \\
$\begin{array}{l}\text { Ignoring censoring } \\
\text { Self-Reported Value - } \\
\text { Parsimonious }\end{array}$ & 0.68 & 0.19 & 0.15 & 0.11 \\
\hline Self-Reported Value - Median & 0.67 & 0.19 & 0.15 & 0.11 \\
\hline Rental Price & 0.68 & 0.19 & 0.15 & 0.11 \\
Rental Price - Parsimonious & 0.28 & 0.29 & 0.25 & 0.20 \\
\hline Rental Price - Median & 0.83 & 0.13 & 0.10 & 0.06 \\
\hline \hline
\end{tabular}

All models based on 99 observations (one observation per community). 
Figure 1. Map of Study Area.

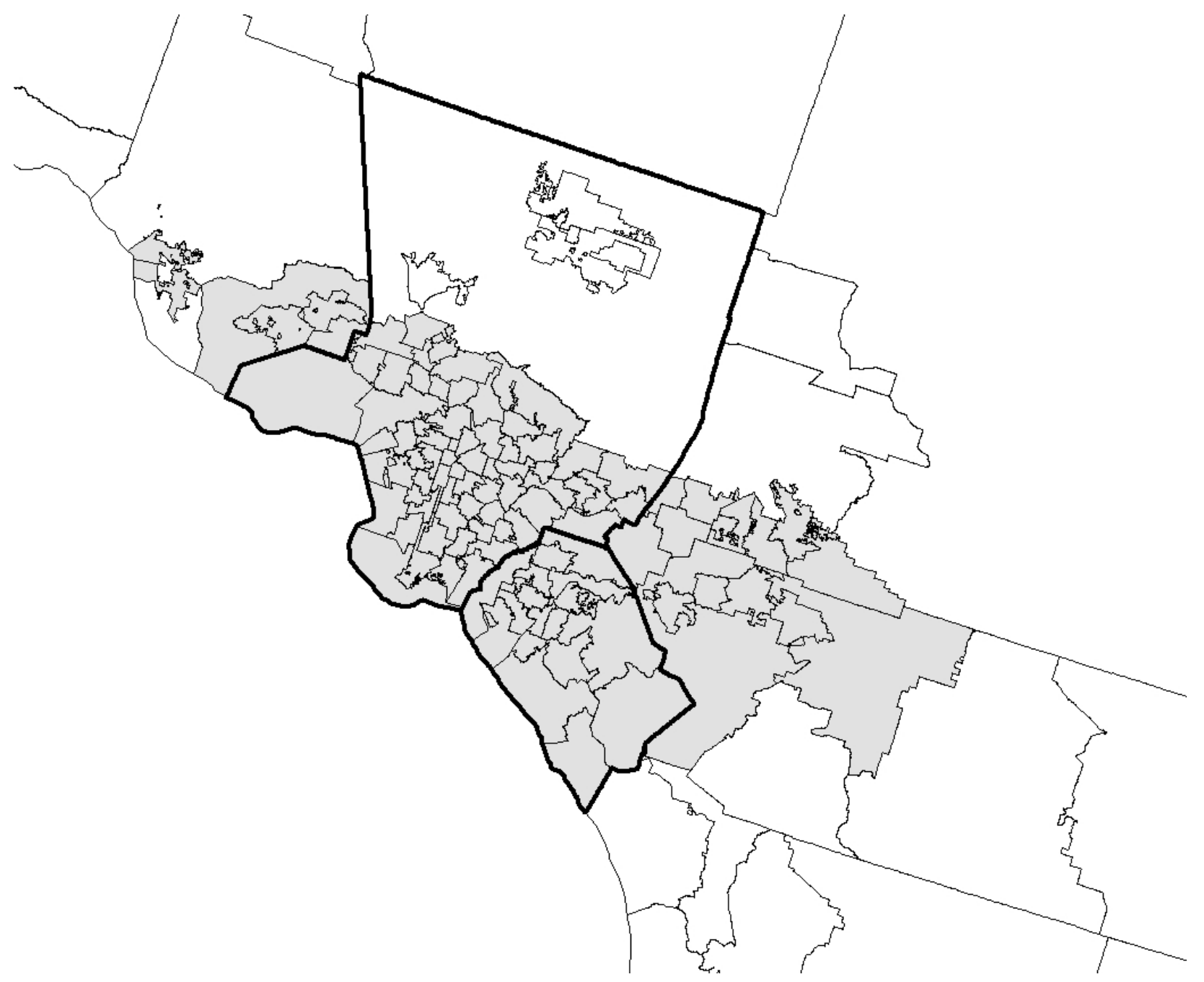




\section{Figure 2. Comparison of Community Price Indices across Data Sources}

Panel A. Indices using self-reported values vs. transactions prices

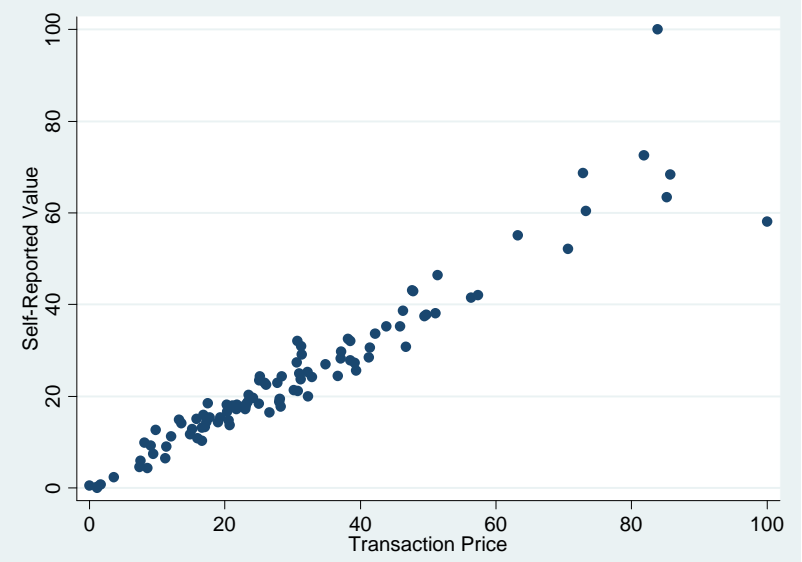

Panel C. Indices using tax assessments vs. transactions prices

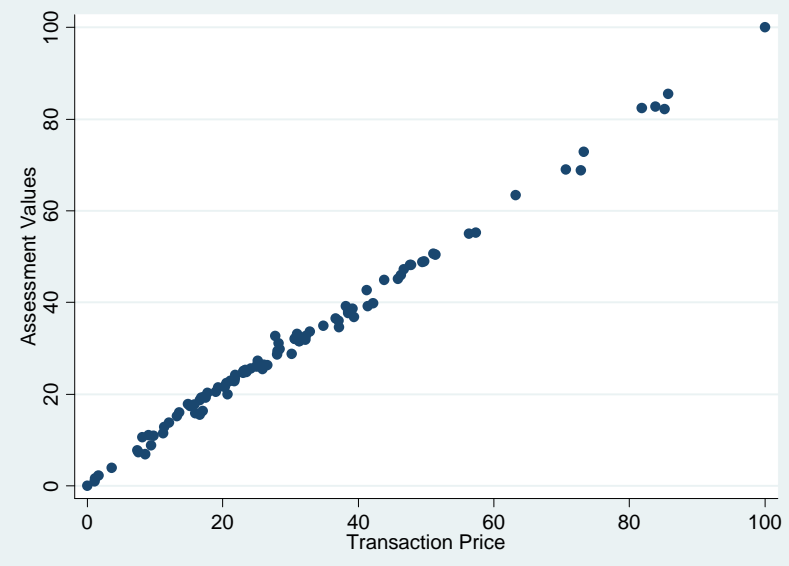

Panel E. Indices using rental prices vs. selfreported values

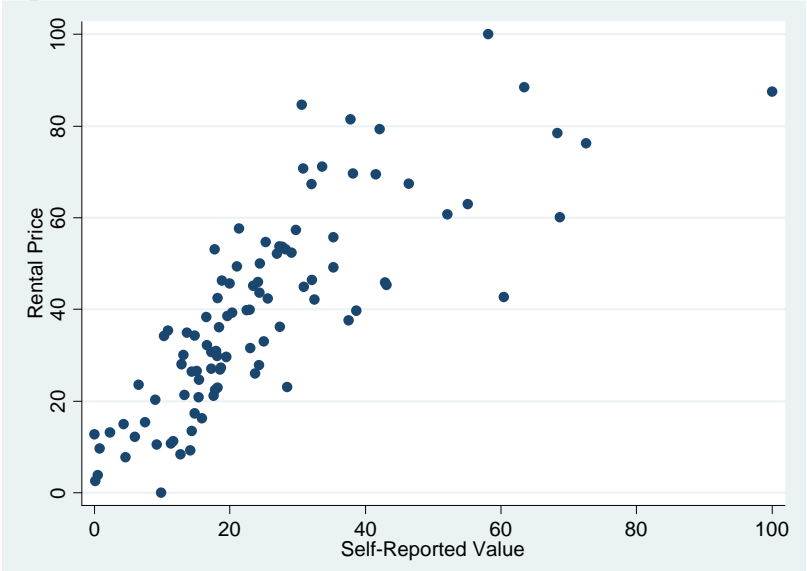

Panel B. Median-based vs. micro-based indices using self-reported values

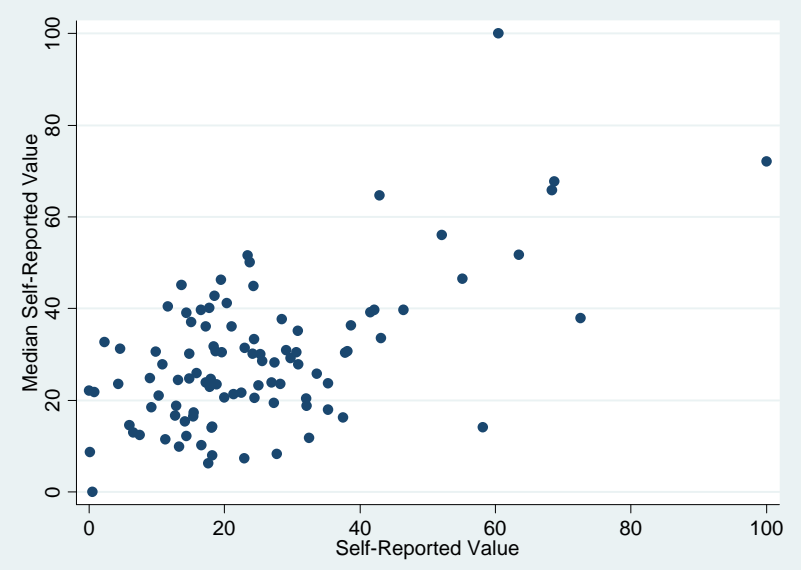

Panel D. Indices using rental prices vs. transaction prices

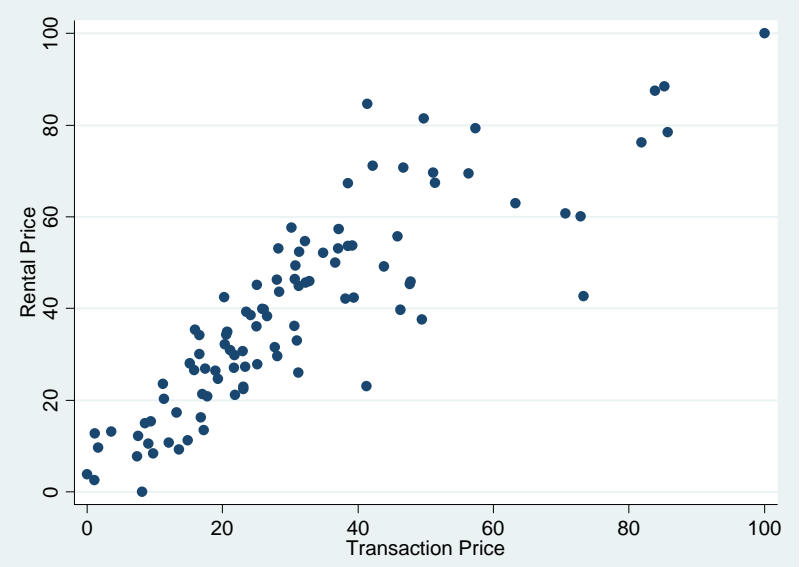

Panel F. Median-based vs. micro-based indices using rents

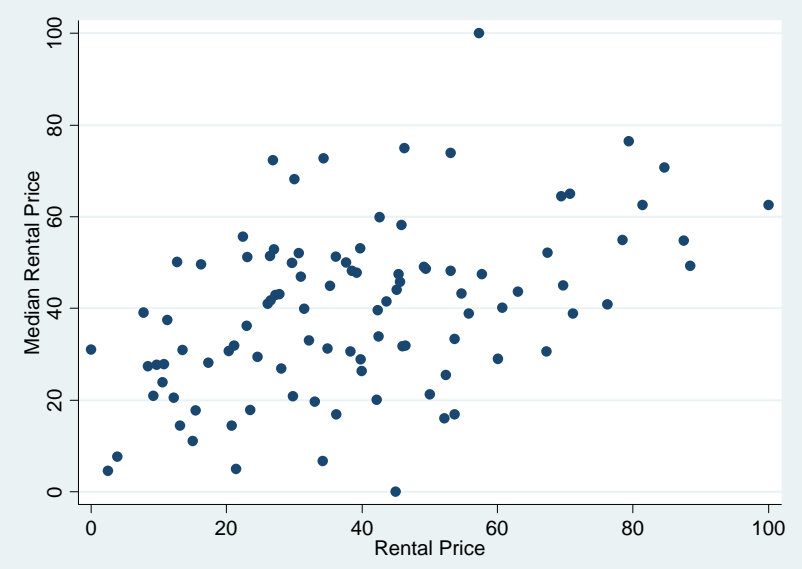


Figure 3. Comparison of Community Price Indices with Average Income

Panel A. Transactions Prices

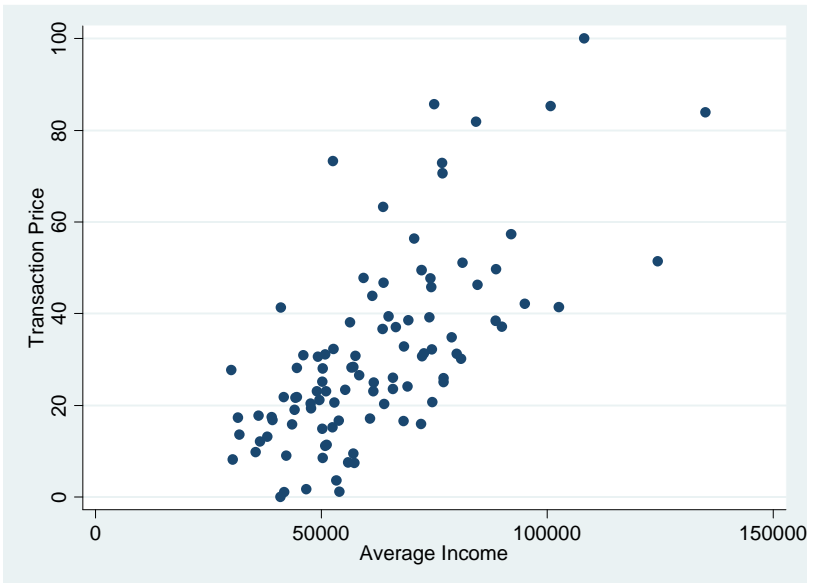

Panel C. Median-based Self-Reported Values

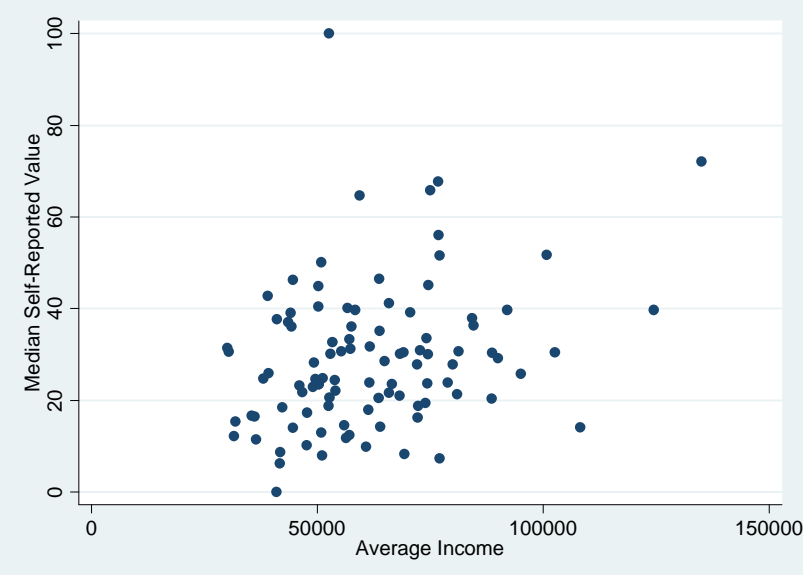

Panel E. Median-based Rental Prices

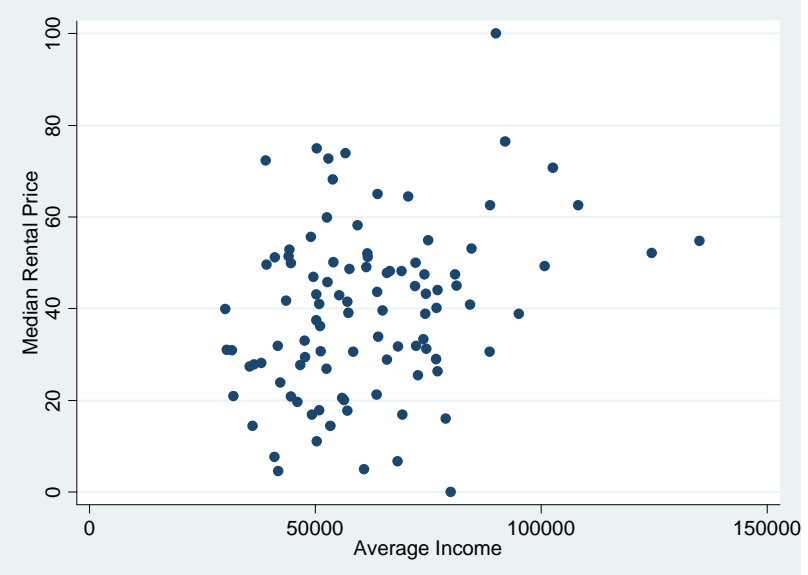

Panel B. Self-Reported Values

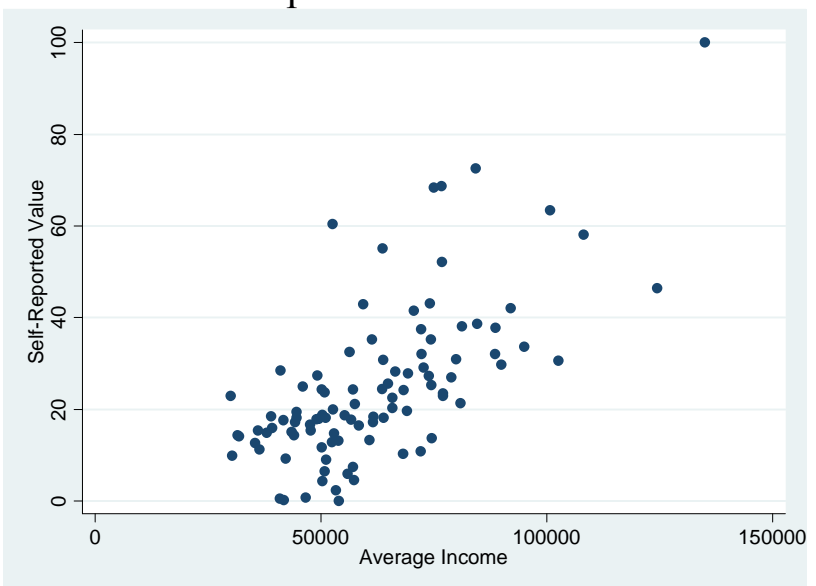

Panel D. Rental Prices

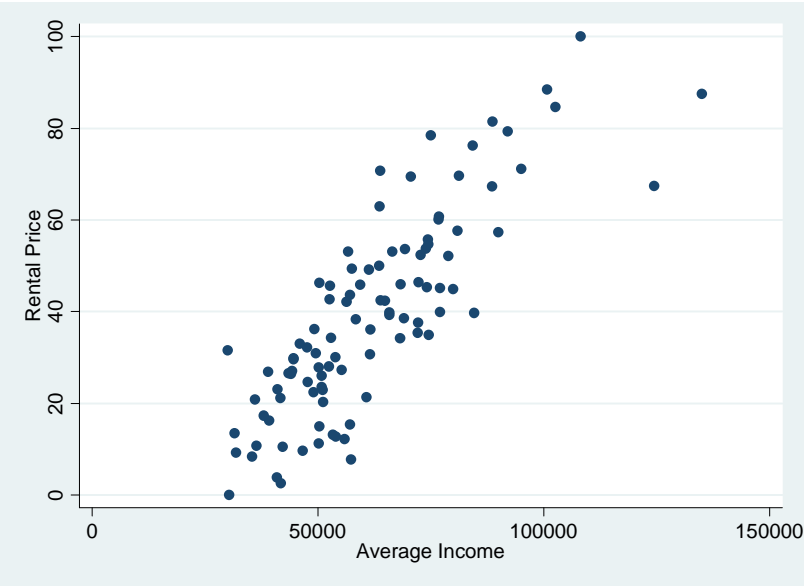

